\title{
Sagittal Suture of the Human Cranium and the Time of Closing
}

\author{
Sutura Sagital en el Cráneo Humano y el Tiempo de Cierre \\ "Janice Chaim Alves; ${ }^{* *}$ Gabriela Cavallini Wafae; ${ }^{*}$ Daniela de Paula Coelho; ${ }^{* * *}$ Nader Wafae; \\ "Viviane de Assis Coelho; ${ }^{* * *}$ Eduardo Pereira \& ${ }^{* * *}$ Cristiane Regina Ruiz
}

AlVES, J. C.; WAFAe, G. C.; COElHO, D. D. P.; WAFAE, N.; COELHO, V. D. A.; PEREIRA, E. \& RUIZ, C. R. Sagittal suture of the human cranium and the time of closing. Int. J. Morphol., 27(2):469-473, 2009.

SUMMARY: The observation of the stage of ossification of the sagittal suture has been adopted as possible approach of age evaluation in anthropology and legal medicine, as area of cranial pathologies: craniosynostosis and scaphocephaly and as diagnosis resource in tomographies. Regarding it, we found many controversies in the specialized literature, thus we decided to accomplish this research with the following objectives: to examine the ossification of the external surface of the sagittal suture, observing eventual differences due to age, sex and ethnic group. Our material consists of 88 dry craniums of variable ages, both sexes belonging to the ethnic groups: white and black. In that material we observed that: with progression of age, the relation between age and stage of ossification of the sagittal suture stops existing. The statistical analysis didn't demonstrate significant differences between sexes and ethnic groups in the stages of ossification of the sagittal suture. The ossification of the sagittal suture starts developing from the posterior third.

KEY WORDS: Sutures; Synostosis; Anthropology; Aging.

\section{INTRODUCTION}

The fibrous tissue in the sagittal suture between the parietal bones presents the tendency of becoming ossified with time and it can disappear in the senior individual (Testut, 1929).

The premature ossification of that suture is associated to several cranial pathologies: craniosynostosis (Woolley et al., 2005), scaphocephaly (Weinzweig et al., 2002), plagiocephaly (Kabbani \& Raghuveer, 2004) which demand the accomplishment of surgeries for their correction; otherwise serious encephalic consequences and deformities of the cranium will happen (Ocampo \& Persing, 1994).

Modern imaging resources as tomographies have been used in the diagnosis of those premature ossifications of the suture (Pollack et al., 1997; Perlyn et al., 2001; Smith et al., 2002).

The utilization of the stage of ossification of that suture as standard for estimation of the age in legal medi- cine and in anthropology has been generating controversies: Meindl \& Lovejoy (1985), Hershkovitz et al. (1997), Lynnerup \& Jacobsen (2003), Sahni et al. (2005), Bednarek et al. (2005), Sabini \& Elkowitz (2006). The ossification would begin in the end of the third decade (Stanley, 1982), the time of closing is very variable, beginning from the internal part between 30 and 40 years of age and the external part 10 years later (Warwick \& Williams, 1973), the synostosis process begins deeply and extends slowly to the superficial part and in some middle age craniums they can be obliterated in the external surface (Romanes, 1972). To DiDio (1998) the sagittal synostosis is pathological and it is characterized by the appearance of ossification centers in the line of the suture. In research accomplished in India, Sahni et al., they conclude that the obliteration of the sutures is more premature in the male sex, it could originate at the endocranial surface and that the beginning and the total obliteration are so variable it is impossible to determine them.

\footnotetext{
* Centro Universitário São Camilo - São Paulo - SP, Brazil.

** Centro Universitário Nove de Julho - São Paulo -SP, Brazil.

*** Discipline of the Human Anatomy of Centro Universitário São Camilo - São Paulo - SP, Brazil.
} 
In spite of such important applications and controversies, the specialized literature demonstrated shortage of more detailed data regarding the form as the process of ossification of the sagittal sutures developes in individuals without pathologies. The objectives of this research consist of examining the ossification of the external surface of the sagittal suture, observing eventual differences in function of the factors of variations: age, sex and ethnic group.

\section{MATERIAL AND METHOD}

Randomly, 88 dry craniums of adult individuals were researched, 45 masculine and 43 feminine belonging to the laboratory of Anatomy of UNIFESP which ages varied from 20 to 87 years, being 48 white and 40 black. The craniums didn't present signs of pathologies that could compromise the normal process of ossification. For the determination of the ethnic group we considered the constant information of the official book of registrations of the laboratory and confirmed it by the external analysis of the cranium.

We adopted the division in just three age groups to avoid dispersions of data.

The extension of the sagittal suture was measured with digital caliper rule Mitutoyo standardizing as points of references: initial the junction point with the coronal suture and final the junction with the lambdoid suture, soon after that distance was divided in thirds: anterior, medium and posterior for accompaniment of the ossification process.

In the statistical analysis of our results we used the test of the qui square when the objective was to evaluate the relation among variables.

\section{RESULTS}

Age. Observing the results obtained in function of age we verified that the sagittal suture is entirely preserved in the group with younger age among 20-35 years (41\%) (Fig. 1) while in the other groups with superior ages we didn't find differences what could suggest that after a certain age there is no longer relation between preserved suture and age.

This independence between age and obliteration of the suture is confirmed by the results obtained for the cases of complete obliteration of the suture not being progressive with the age, that is $35.7 \%$ for ages between 35 and 50 years and $19.0 \%$ for ages equal or above 51 years. When we compare the complete obliteration (synostosis) (Fig. 2) among those age groups we observe significant statistical difference between the group 20 - 35 and the other groups with superior ages, however significant statistical difference doesn't exist when we compare the presence of preserved suture.

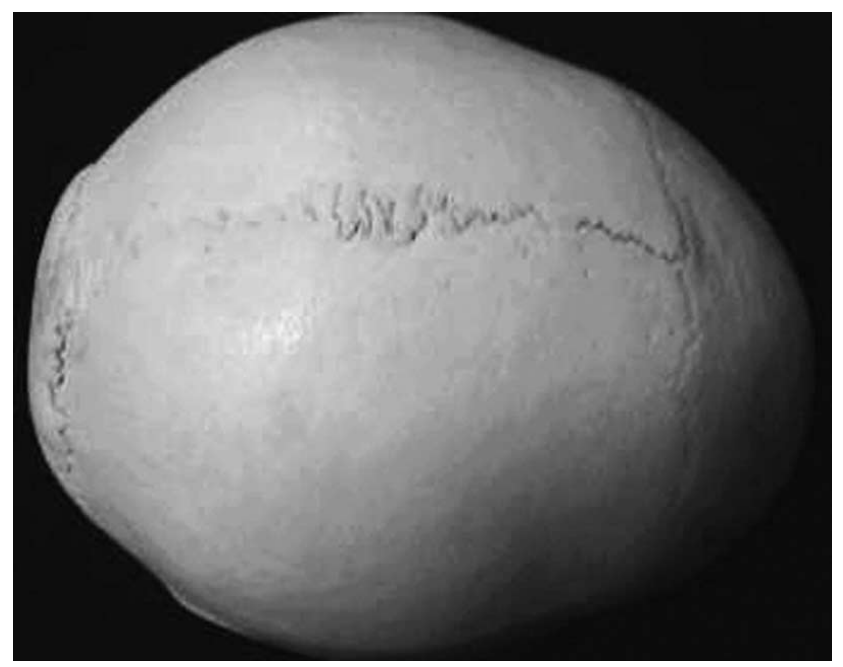

Fig. 1. Sagittal suture partially closed starting in the posterior third.

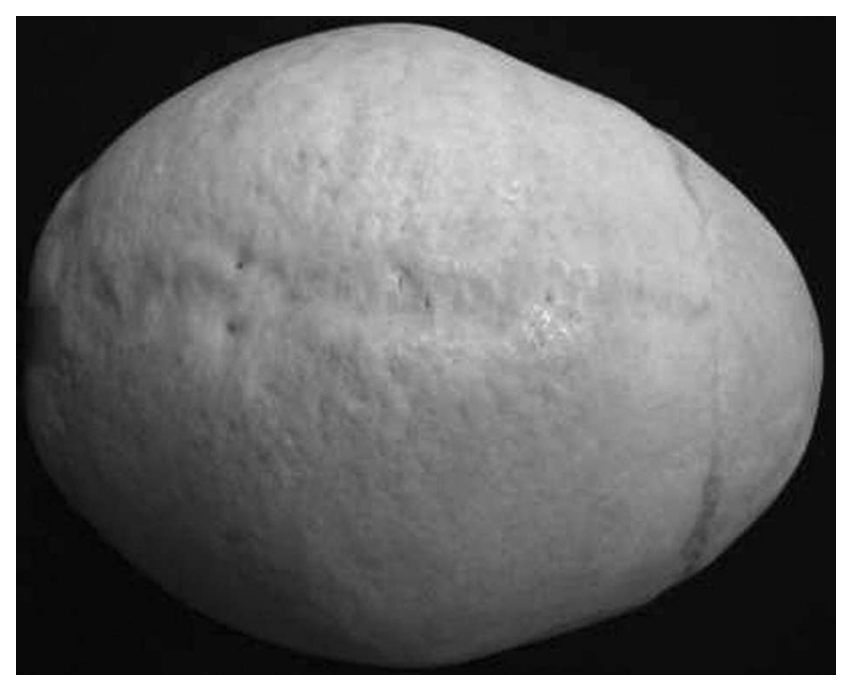

Fig. 2. Sagittal suture closed (synostosis).

We also didn't obtain progression with the age when we analyzed the partial closing of the suture.

Sex. We didn't observe any association between age and the masculine sex and possible relations with the development of the sagittal suture. This signifies that in the masculine sex the preservation of the suture or its partial or total obliteration 
is not related to the individual's age. The synostosis is similar in the extreme groupings of ages.

However in the feminine sex we observed some associations between age and development of the sagittal suture. The suture is more preserved in the group of younger age between 20 and 35 years and the synostosis is also small in that same group. But for the superior groupings of age association relations are also not observed. The statistical analysis didn't demonstrate significant differences between the sexes in the references preserved suture or fused. There also was no significance in the considered age groups.

Ethnic group. Differences were not observed in the sagittal suture in relation to the white and black ethnic groups. The statistical analysis didn't demonstrate significant differences between the ethnic groups in the references preserved suture or fused. There also was no significance in the considered age groups.

Closing of the sagittal suture. In the craniums where the external part of the sagittal suture appeared just partially fused we identified the sequence in which its closing occurred and we verified that it begins by the posterior third (Fig. 3) with larger medium incidence $(58.6 \%)$ passing right after to the medium third $(27.6 \%)$ and being the final part to the anterior third $(13.8 \%)$. When we analyze the closing period

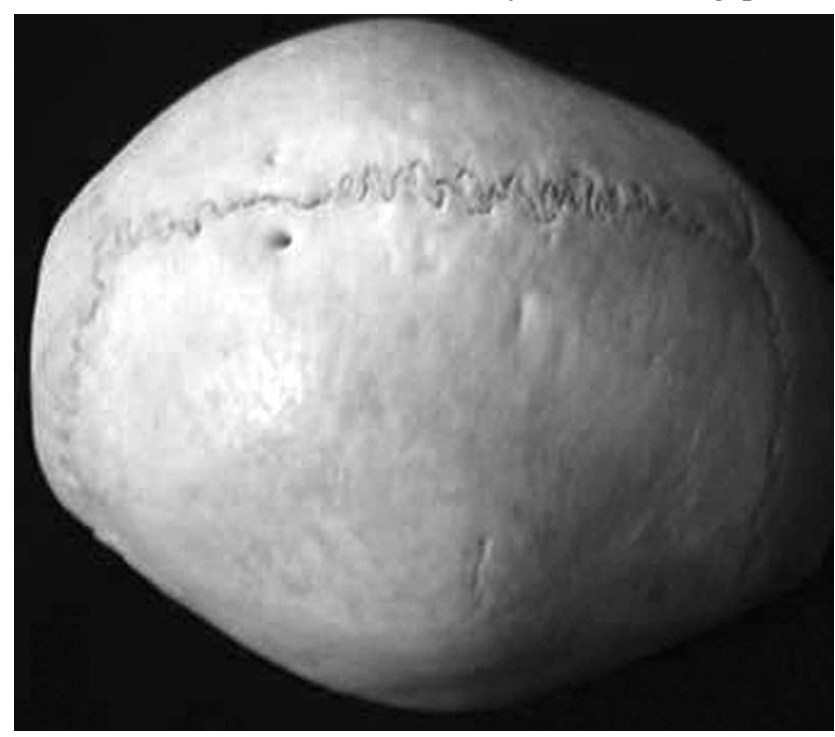

Fig. 3. Sagittal suture preserved.

comparing its occurrence in the sexes and in the ethnic groups we didn't observe significant differences. However, the statistical analysis demonstrated significant difference between the beginning of the closing of the suture by the posterior third when compared with the incidence by the medium and anterior thirds

\section{DISCUSSION}

The correlation between the development stage in which the sutures of the cranium are verified and the possibility of evaluation of the person's age has been motivating many researches in legal medicine (Meindl \& Lovejoy) and in anthropology (Hershkovitz et al.) as well as regarding its application in neurosurgery (Jane et al., 2000).

Lynnerup \& Jacobsen concluded that below 40 years of age there is relation between development and age, but that any precise determination of age in seniors is impossible. Hershkovitz et al. verified that the closing of the sagittal suture occur independent of the age and it is not good for determination of the age of the skeleton.

The results of Bednarek et al., demonstrated the impossibility of precise evaluation of the age based on the closing of the suture. Sabini \& Elkowitz didn't find significance between age and degree of obliteration of the suture.

In our material we verified that the sagittal suture is entirely preserved in the group with younger age between 20-35 years $(41 \%)$ while in the other groups with superior ages we didn't find differences, thus it seems to us that after a certain age there is no longer more relation of preserved suture and age.

This independence between age and obliteration of the suture in superior ages is confirmed by the results obtained for the cases of complete ossification of the suture non progressive with age.

There is significant statistical difference considering the complete obliteration between the age groups with 20 35 years and the groups with superior ages. The same is not observed when we compare the presence of preserved suture. Progression doesn't also exist between the closing sequence and age, Meindl \& Lovejoy affirm differently, to whom the progression in the development of the closing of the suture has association with the age.

Sabini \& Elkowitz didn't find significant disparities in the development of the sagittal suture in the comparisons between the sexes. Hershkovitz et al., present differences in the patterns of closing of the suture. The frequency of craniums with open sutures decreased continually with age. In all the age groups, there were significantly more women with open sutures than men. The sexual differences would be minor for Hauser et al. (1991). To Sahni et al. (2005) the permeability of the suture decreases progressively in males, 
but in the females the relation with the age was irregular and in women with more than 50 years he didn't find complete obliteration. Yet Meindl \& Lovejoy affirm to have found significant differences related to the sex.

We didn't observe any association of relation between age and masculine sex. This means that in the masculine sex the preservation of the suture or its partial or total obliteration is not attach to the individual's age. However in females we observed some associations between age and development of the sagittal suture. The suture is more preserved in the group of younger age between 20 and 35 years, but in the groups of superior ages, association of relation is also not observed. The statistical analysis didn't demonstrate significant differences between the sexes in the references preserved or fused sutures.

Although they don't mention the differences found in relation to the ethnic groups, Meindl \& Owen Lovejoy affirm they found dissimilarities. In Hershkovitz et al., the ossification is more premature in black males. In our material differences were not observed in the sagittal suture in relation to the white and black ethnic groups according to statistical analysis. There were also not significant differences in the considered age groups.

\section{CONCLUSIONS}

With the progression of the age, association between age and degree of ossification of the sagittal suture no longer exists.

The statistical analysis didn't demonstrate significant differences between the sexes in the stage of ossification of the sagittalsuture.

The statistical analysis didn't demonstrate significant differences between the ethnic groups in the stage of ossification of the sagittal suture.

The ossification of the sagittal suture develops from the posterior third.

ALVES, J. C.; WAFAE, G. C.; COELHO, D. D. P.; WAFAE, N.; COELHO, V. D. A.; PEREIRA, E. \& RUIZ, C. R. Sutura sagital en el cráneo humano y el tiempo de cierre. Int. J. Morphol., 27(2):469-473, 2009.

RESUMEN: La observación de los estados de osificación de la sutura sagital han sido adoptados como posibles criterios de evaluación de la edad en Antropología y Medicina Legal, como un área de patologías craneales: craneosinostosis, escafocefalia y como recursos diagnóstico en tomografias. Encontramos muchas controversias en la literatura especializada, por lo tanto, decidimos realizar esta investigación con el objetivo de examinar la osificación de la superficie externa de la sutura sagital, observando eventuales diferencias debidas a la edad, sexo y grupo étnico. Nuestro material se componía de 88 cráneos secos de individuos de diferentes edades, de ambos sexos, pertenecientes a los grupos étnicos blancos y negros. En el material se observó: progresión de la edad y relación entre la edad y la etapa de osificación de la sutura sagital. El análisis estadístico no demostró diferencias significativas entre sexos y grupos étnicos en las etapas de la osificación de la sutura sagital. La osificación de la sutura sagital comienza a producirse desde el tercio posterior.

PALABRAS CLAVE: Suturas; Sinostosis; Antropología; Edad.

\section{REFERENCES}

Bednarek, J.; Bloch-Boguslawska, E.; Engelgardt, P.; Wolska, E. \& Sliwka, K. The degree of closure of the cranial sutures as a quick method for adult age evaluation in autopsy. Arch. Med. Sadowej Kryminol, 55(3):185-9, 2005.

Di Dio, L. J. A. Tratado de anatomia aplicada. Ed. Poluss Editorial, São Paulo, 1998.

Hauser, G.; Manzi, G.; Vienna, A. \& De Stefano, G. F. Size and shape of human cranial sutures - a new scoring method. Am. J. Anat., 190(3):231-44, 1991.
Hershkovitz, I.; Latimer. B.; Dutour, O.; Jellema, L. M.; Wish-Baratz, S.; Rothschild, C. \& Rothschild, B. M. Why do we fail in aging the skull from the sagittal suture? Am. J. Phys. Anthropol., 103(3):393-9, 1997.

Kabbani, H. \& Raghuveer, T. S. Craniosynostosis. Am. Fam. Physician, 69(12):2863-70, 2004.

Jane, J. A. Jr.; Lin, K. Y. \& Jane, J. A. Sagittal synostosis. Neurosurg. Focus, 15;9(3):e3, 2000.

Lynnerup, N. \& Jacobsen, J. C. Brief communication: age and fractal dimensions of human sagittal and coronal 
ALVES, J. C.; WAFAE, G. C.; COELHO, D. D. P.; WAFAE, N.; COELHO, V. D. A.; PEREIRA, E. \& RUIZ, C. R. Sagittal suture of the human cranium and the time of closing. Int. J. Morphol., 27(2):469-473, 2009.

sutures. Am. J. Phys. Anthropol., 121(4):332-6, 2003.

Meindl, R. S. \& Lovejoy, C. Ectocranial suture closure: a revised method for the determination of skeletal age at death based on the lateral-anterior sutures. Am. J. Phys. Anthropol., 68:57-66, 1985.

Ocampo, R. V. \& Persing, J. A. Sagittal synostosis. Clin. Plast. Surg., 21(4):563-74, 1994.

Perlyn, C. A., Marsh, J. L., Pilgram, T. K. \& Kane, A. Plasticity of the endocranial base in nonsyndromic craniosynostosis. Plast. Reconstr. Suirg., 108(2):294301, 2001.

Pollack, I. F., Losken, H. W. \& Fasick, P. Diagnosis and management of posterior plagiocephaly. Pediatrics 99(2):180-5, 1997.

Romanes, G. J. Cunningham's texbook of anatomy. $11^{\text {th }} \mathrm{Ed}$. Oxford University Press, London, 1972.

Sabini, R. C. \& Elkowitz, D. E. Significance of differences in patency among cranial sutures. J. Am. Osteoaph. Assoc., 106(10):600-4, 2006.

Sahni, D.; Jit, I.; Neelam, \& Sanjeev, I. Time of closure of cranial sutures in northwest Indian adults. Forensic Sci. Int., 148 (2-3):199-205, 2005.

Smith, D. R.; Limbird, K. G. \& Hoffman, J. M. Identification of human skeletal remains by comparison of bony details of the cranium using computerized tomographic scans. J. Forensic Sci., 47(5):937-9, 2002.

Testut, L. Traité d'anatomie humaine. 8. Ed. Librairie Octave Doin, Paris, 1929.

Warwick, R. \& Williams, P. L. Gray's Anatomy. 35 ed. Longman, Edinburgh, 1973.

Weinzweig, J.; Baker, S. B.; Whitaker, L. A.; Sutton, L. N. $\&$ Bartlett, S. P. Delayed cranial vault reconstruction for sagittal synostosis in older children: am algorithm for tailoring the reconstructive approach to the craniofacial deformity. Plast. Reconstr. Surg., 110(2):397-408, 2002.

Woolley, E. J.; Richardson, D. \& May, P. Management of craniofacial abnormalities. Hosp. Med., 66(7):405-10, 2005.
Correspondence to:

Dra. Cristiane Regina Ruiz

Centro Universitário São Camilo - SP

Rua Roberto Koch, 34

CEP: 04221-060

Ipiranga - São Paulo

BRASIL

Phone: 551165911264

Phone fax: 551161694000

Email: crisruiz@scamilo.edu.br

Received: 18-08-2008

Accepted: 17-09-2008 
